\title{
The Republican war on science
}

\author{
Chris Mooney \\ Basic Books. New York, New York, USA. 2005. \\ 342 pp. \$24.95. ISBN: 0-465-04675-4 (hardcover).
}

Reviewed by Alan D. Attie

University of Wisconsin-Madison, Madison, Wisconsin, USA.

E-mail: attie@biochem.wisc.edu grew up believing that environmentalism was a common sense approach to life, grounded in epidemiology and basic science. Over time, I have seen environmentalism, along with other areas where science informs public policy, derided and marginalized. How did this happen?

In his important and alarming indictment, The Republican war on science, Chris Mooney tells how, beginning in the 1970s, the consensus of the scientific community ran afoul of corporate interests. To neutralize the influence of academic scientists, corporate-funded "think tanks" and "institutes" proliferated to produce "experts" who would offer what later became labeled by their Congressional supporters as "sound science" to counter the "junk science" of university-based scientists and expert panels of scientific organizations.

The Office of Technology Assessment, a highly respected arm of Congress, issued more than 750 reports reflecting the consensus of the scientific community on a wide range of issues. Under pressure from corporate lobbyists, it was abolished by the Gingrich revolution of 1995 . In its place, we now have a "science court" in which politicians listen to "experts" of opposing views and then draw their conclusions.

Mooney is Washington correspondent for Seed magazine and senior correspondent for the American Prospect. He documents a strategy born during the tobacco industry's years of obfuscation over the health risks of smoking. An infamous 1960s Brown \& Williamson memo states, "Doubt is our product, since it is the best means of competing with the 'body of fact' that exists in the mind of the general public. It is also a means of establishing controversy." The formula is to amplify uncertainties, cherry-pick experts, attack individual scientists, marginalize the tradi- tional role of distinguished scientific bodies and get the media to report "both sides" of a manufactured controversy. The formula has been successfully applied to missile defense, acid rain, the ozone layer, global warming, mercury in fish, sugar and obesity, evolution, sex education, contraception, AIDS prevention, and stem cell research.

To further reduce the impact of university-based science, Congress passed the Data Quality Act. This law requires government agencies to respond to complaints over data used in issuing reports to the public. It enables corporations to sue government agencies that reject their own data quality. The end result is regulatory paralysis. Mooney describes the use of this law to harass UC Berkeley endocrinologist Tyrone Hayes after he published a study on the estrogen-mimetic effects of atrazine, a widely used pesticide.

In 2004, the Union of Concerned Scientists produced a document highly critical of the Bush administration for suppressing, modifying, and distorting reports of its advisory committees, using a political process for vetting candidates for advisory committees, using respected scientific agencies to disseminate false scientific information, and weakening the Endangered Species Act. The document was signed by thousands of scientists, including 48 Nobel laureates, 62 National Medal of Science recipients, and 135 members of the National Academy of Science.

Language figures prominently in this story in a way eerily reminiscent of the revisions and doublespeak emanating from the Ministry of Truth in Orwell's 1984. For example, the sound science of diet and obesity can be sampled at the Center for Consumer Freedom. A broader view of the junk science of university-based research is at junkscience.com.

Mooney's book is unabashedly polemical, but Mooney redeems himself by his meticulous research. He repeatedly emphasizes how Republican politicians abuse science in the service of their corporate and religious right sponsors. He explains that, indeed, Republicans abuse science far more than do Democrats but does cite the exaggerated claim made by presidential candidates John Edwards and John Kerry that support for stem cell research would have enabled actor Christopher Reeve to recover from his spinal cord injury.

Mooney castigates the news media for conceding the impression of scientific controversy in areas where there is wide scientific consensus, if not unanimity. For example, the media is complicit in propagating the hoax that, among scientists, there is scientific controversy over evolution, that evolution is "just" a theory, and that intelligent design is a scientific theory.

Mooney's prescription is to support organizations such as the National Center for Science Education, support moderate Republicans, and oppose antiscience extremist politicians. My own opinion is that this is a wake-up call to us as world citizens, scientists, and educators. Critical evidence-based thinking is too important to be left in the exclusive domain of scientists. It should be considered part of a complete education, beginning in grade school. We need to communicate more frequently and effectively with our politicians, regardless of political affiliation. The stakes are high, for we cannot afford to make wrong judgments on such issues as disease prevention, global warming, missile defense, toxic waste, HIV prevention, and the ongoing evolution of the avian flu virus. 